\title{
IMPLEMENTASI KONVENSI PENGHAPUSAN SEGALA BENTUK DISKRIMINAS TERHADAP PEREMPUAN (CEDAW) DAN KORELASINYA TERHADAP KETIDAKSETARAAN GENDER DI CINA
}

\author{
Siti Hediati Rahminita \\ Program Studi Ilmu Hubungan Internasional, FISIP Universitas Padjadjaran \\ Jl. Raya Bandung Sumedang, Hegarmanah, Jatinangor, Kabupaten Sumedang, Jawa Barat \\ 45363, Indonesia \\ e-mail: hediatis@gmail.com
}

\begin{abstract}
ABSTRAK
Tulisan ini menelisik tentang hubungan antara implementasi Convention on Elimination of All Forms of Discrimination against Women (CEDAW) di Cina dan ketidaksetaraan gender di Cina khususnya dalam pasar tenaga kerja. Konvensi internasional yang dikeluarkan oleh Perserikatan Bangsa - Bangsa (PBB) pada tahun 1981 ini berusaha untuk meniadakan segala jenis diskriminiasi terhadap kaum perempuan. Cina menjadi salah satu negara yang meratifikasi konvensi tersebut. Dalam proses implementasi pilar - pilar konvensi ini, Cina dengan gencar mempromosikan tentang penghapusan segala jenis diskriminasi terhadap kaum perempuan. Akan tetapi, bagaimana dengan adanya ketidaksetaraan gender yang terjadi di pasar tenaga kerja Cina. Bagaimana Cina memberantas ketidaksetaraan gender yang marak di negaranya. Pembahasan isu tersebut akan dikaitkan dengan pandangan feminisme.
\end{abstract}

Kata Kunci: konvensi CEDAW, ketidaksetaraan gender, feminism

\section{PENDAHULUAN}

Republik Rakyat Cina merupakan negara dengan populasi penduduk 1.373.541.278 jiwa (Worldbank.org, 2015). Jumlah tersebut menempatkan Cina pada negara dengan jumlah penduduk tertinggi di dunia. Sejalan dengan itu, tenaga kerja yang ada di Cina terbilang sangat banyak. Tercatat dari data yang dipaparkan oleh The World Bank terdapat sekitar 3.384.000 jiwa yang menjadi buruh. Jumlah tersebut kian bertambah sejalan dengan berjalannya waktu. Dengan kenyataan tersebut, pasar tenaga kerja di Cina menjadi sangat ramai.

Sejalan dengan itu, pergantian kebijakan ekonomi di Cina tidak hanya terjadi satu kali saja, berbagai kebijakan baru kerapkali diterapkan guna menghasilkan sistem perekonomian yang terbaik. Tercatat dari tahun 1978 terdapat delapan belas kali adanya perubahan - perubahan pada aspek perekonomiannya. Perubahan kebijakan pada tahun 1978 memberikan dampak yang cukup besar bagi pertumbuhan jumlah tenaga kerja di Cina yang membuat pasar tenaga kerja di Cina semakin membludak. Sejak saat itu, terdapat peningkatan kesenjangan gender dalam beberapa indikator di pasar tenaga kerja. Terdapat penurunan partisipasi angkatan kerja perempuan di Cina dengan cukup drastis.

Pada tahun 1981 konvensi internasinal Convention on Elimination of All Forms of Discrimination against Women (CEDAW) dikeluarkan oleh Perserikatan Bangsa - Bangsa yang ditujukan untuk meniadakan segala jenis diskriminasi terhadap kaum perempuan.. Bersama dengan 64 negara lainnya, Cina telah 
menandatangani konvensi internasional tersebut. Tidak lama setelah itu, Cina langsung menyetujui untuk ikut serta meratifikasi konvensi tersebut. Dalam kata lain, Cina telah setuju untuk memberikan andil terhadap peniadaan segala macam bentuk diskriminasi yang ada. Cina kerapkali menerima tanggapan positif terkait dengan kebijakan - kebijakan yang dilaksanakan yang berhubungan dengan upaya penghapusan diskriminasi terhadap perempuan. Di sisi lain, kesenjangan gender dalam pasar kerja masih kerap ditemui di Cina. Tingkat partisipasi angkatan kerja wanita dari waktu ke waktu semakin menurun pada tingkatan yang lebih cepat dibanding dengan tingkat angkatan kerja kaum pria. Maka, perlu dipertanyakan bagaimana implementasi dari konvensi CEDAW di Cina ini. Hal ini disebabkan karena dengan adanya ratifikasi Cina mengenai konvensi ini, maka Cina harus siap dalam upaya menghapuskan segala bentuk diskrimasi yang ada.

\section{PEMBAHASAN}

The Convention on the Elimination of All Forms of Discrimination against Women (CEDAW) diadopsi oleh Majelis Umum Perserikatan Bangsa - Bangsa pada tahun 1979 (Nations). Konvensi ini kerapkali disebut sebagai instrument perundang - undagan mengenai hak perempuan secara internasional. Di dalamnya, konvensi ini terdiri dari pembukaan dan tiga puluh artikel yang mendefinisikan tentang bagaimana jenis - jenis diskriminasi terhadap perempuan. Jelas sekali bahwa konvensi ini dibentuk untuk memberantas segala bentuk ketidaksetaraan yang ada antara kaum perempuan dan kaum laki - laki.

Secara umum, konvensi ini memberikan fondasi dalam rangka mewujudkan kesetaran antara kaum perempuan dan kaum laki - laki. Hal tersebut dipastikan dengan tersedianya akses terhadap kesetaraan itu sendiri baik dalam kehidupan politik dan ruang - ruang publik lainnya dari mulai pendidikan, kesehatan, dan ketenagakerjaan. Negara - negara yang ikut andil dalam konvensi ini telah siap untuk melakukan segala jenis tindakan yang tepat untuk melindungi kaum perempuan. Dengan begitu, mereka dapat menikmati hak asasi dan kebebasan fundamental yang dimiliki. Hak asasi dan kebebasan memang telah menjadi dua instrument yang sangat fundamental untuk dimiliki oleh setiap insan manusia. Hal ini menunjukan bahwa segala hal yang tidak sejalan dengan hak asasi sudah seharusnya diperbaiki.

Terlepas dari itu, jika melihat kembali pada tahun 1995 di mana Perserikatan Bangsa - Bangsa memutuskan untuk menyelenggarakan sebuah Konferensi Dunia Keempat tentang perempuan di Beijing membuat perhatian dunia terfokus terhadap kondisi perempuan di Cina. Berkaca pada sejarah yang ada, perempuan Cina telah lama tunduk dan pasrah terhadap penghinaan serta penindasan yang sangat brutal dalam tatanan masyarakat feodal, semi - feodal, hingga semi - kolonial. Setelah mengalami masa suram tersebut, kaum perempuan di Cina akhirnya mampu menikmati kebebasan dan hak yang dimilikinya. Cina menyebutkan bahwa hukum di negaranya telah menjamin kesetaraan antara kaum perempuan dengan kaum laki - laki. Namun, dalam kehidupan nyata, hak kaum perempuan untuk mendapatkan kesetaraan dalam pekerjaan, partisipasi politik, pendidikan, dan kehidupan berkeluarga belum sepenuhnya terwujud.

Dengan dimulainya pengimplementasian dari konvensi CEDAW, mulanya Cina sangat optimis mampu memerangi segala jenis tindakan diskriminasi pada perempuan. Pun dengan kondisi Cina yang mengalami pertumbuhan level ekonomi yang sangat tinggi dan cepat. Namun, di balik itu semua ternyata tidak ada kemerataan distribusi kesejahteraan yang dimiliki oleh para penduduk di dalam negeri. Lebih mendasar lagi ialah perihal kesetaraan tentang kaum perempuan dan laki - laki. Ditambah lagi dengan adanya ketidaksetaraan kaum perempuan yang berada di daerah pedesaan terhadap akses mengenai pekerjaan, 
pendidikan, serta kesehatan. Kenyataan tersebut tentunya sudah tidak sesuai dengan apa yang dipaparkan dalam konvensi CEDAW.

Kaum perempuan dan laki - laki jika dilihat dari karakteristik sosio - ekonomi acapkali mengantarkan keduanya terhadap hasil upah yang berbeda. Hal tersebut utamanya disebabkan oleh adanya stereotip mengenai gender. Perlu diingat bahwa dalam dunia kerja, upah merupakan salah satu aspek terpenting yang harus diperhatikan. Jika terdapat ketidaksetaraan dalam pemberian upah maka patut dipertanyakan mengenai integritas dan objektifitas yang dimiliki oleh pemilik pekerjaan tersebut. Perbedaan gender dalam kesetaraan pembayaran upah kerja mampu disebabkan oleh adanya perbedaan berupa diskriminasi kompetensi yang dimiliki. Diskriminasi tersebut disebabkan oleh adanya indikator - indikator yang memberi pengaruh besar di dalamnya. Indikator - indikator tersebut kemudian mulai membentuk stereotype yang akan mengantarkan pemikiran manusia terhadap diskriminasi yang dilakukan dalam berbagai bidang kehidupan. Upah kerja, menjadi salah satunya. Oleh karena itu diperlukan adanya perhatian yang lebih terhadap akses yang dimiliki oleh kaum perempuan untuk mendapatkan pekerjaan yang setara dengan kaum laki - laki, dan mengenai ketersediaan lingkungan yang baik untuk kenyamanan para tenaga kerja.

Berbicara mengenai pengimplementasian konvensi CEDAW di Cina masih terdapat kesenjangan yang sangat signifikan berkaitan dengan hukum formal yang diterapkan di Cina dengan hukum internasional yang ada (Rights, 2006). Kesenjangan tersebut mampu memberikan miskonsepsi mengenai makna sesungguhnya dari diskriminasi yang dimaksud. Miskonsepsi tersebut mampu mengantarkan Cina pada ketidaksesuaian dalam melakukan program dan kebijakan yang seharusnya dilakukan. Kemudian akan terjadi penerapan kebijakan yang tidak memadai dan tidak sejalan dengan mekanisme yang dibangun dalam sistem hukum internasional yang telah ditetapkan.

Terlepas dari itu, pembahasan mengenai ketidaksetaraan gender di Cina telah muncul sejak lama. Pun kebijakan mengenai isu ini telah ditekankan kembali pada kisaran tahun 1990 (Dasgupta, 2015). Dalam kebijakan tersebut dipaparkan bahwa Cina menjamin enam persamaan hak yang dimiliki oleh perempuan dalam bidang - bidang publik seperti pekerjaan, politik, pendidikan, kepemilikan akan property, hak pribadi, dan hak untuk membangun keluarga seutuhnya. Pun prinsip tentang kesetaran upah dalam dunia kerja kembali diabadikan dengan jelas. Hal tersebut ditujukan sebagai bentuk perlindungan terhadap pekerjaan, pendapatan, dan keuntungan yang dimiliki oleh kaum perempuan. Tidak hanya berfokus untuk memperjuangkan harkat dan martabat kaum perempuan saja. Namun, lebih jauh lagi memperjuangkan hak - hak para kaum yang termarjinalkan. Entah itu dalam bidang pekerjaan, pendidikan, maupun bidang kehidupan lainnya.

Selain konvensi CEDAW, Five - Years Plan yang dimiliki Cina — merupakan salah satu kebijakan ekonomi yang dimiliki Cina pada kisaran tahun 1953 sampai pada tahun 1957- menggelorakan target yang serupa mengenai kesetaraan gender yang ada di Cina. Hal tersebut menandakan bahwa Cina harus lebih memperkuat perlindungan terhadap tenaga kerja, kesejahteraan sosial, perawatan kesehatan, bantuan kemanusiaan, dan bantuan hukum bagi kaum perempuan yang berada di Cina. Secara perlahan, Cina membuat kebijakan - kebijakan yang beragam dalam rangka memperjuangkan kesetaraan gender dan memberantas segala bentuk marjinalisasi terhadap umat manusia.

Ketidaksetaran gender memang telah menjadi pembahasan hangat dalam dunia internasional. Jika dilihat dari kacamata perspektif feminisme, memperjuangkan kesetaraan gender merupakan perjuangan yang masih berlangsung sejak lama. Isu mengenai masalah ini dirasa terus menerus berkembang. Ketidaksetaraan 
gender masih sering ditemui dalam berbagai aspek kehidupan. Di Cina khususnya, masih banyak sekali baik kaum pria ataupun perempuan yang percaya bahwa laki - laki lebih pantas berada di area publik dan perempuan lebih baik tinggal di rumah. Kenyataan tersebut secara tersirat menyebutkan bahwa Cina sudah sangat meremehkan potensi yang dimiliki oleh kaum perempuan. Ketidaksetaraan gender ini kemudian diperparah dengan adanya persimpangan dengan aspek - aspek lain seperti kemiskinan, kelas sosial, ras, etnisitas, kepercayaan agama, keadaan fisik, orientasi seksual, identitas sosial, dan sebagainya. Kaum perempuan kerapkali dipandang sebagai manusia yang memiliki banyak kekurangan bahkan lebih parah lagi dianggap lebih terpinggirkan dalam segala aspek kehidupan.

Diskriminasi gender yang terjadi di Cina dalam bidang pekerjaan dan pendidikan disebut sebagai bukti nyata dari tingkat pembelajaran dan pendapatan yang lebih rendah didapatkan oleh para pekerja perempuan daripada para pekerja laki - laki. Sejalan dengan itu, kesenjangan gender dalam partisipasi kerja dan upah pekerjaan masih dapat terkendali di Cina. Akan tetapi, selama dua decade terakhir keadaan tersebut berbalik. Kesenjangan gender di Cina menjadi semakin meningkat. Salah satu penyebabnya ialah semakin dalamnnya integrasi yang dilakukan oleh cina terhadap perekonomian global. Hal tersebut menyebabkan Cina melakukan reformasi kebijakan yang lebih mendalam terkait dengan transisi terhadap perekonomian yang berorientasi pasar. Keadaan tersebut dirasa akan membangkitkan kembali pembagian peran antara kaum perempuan dan kaum laki - laki dalam dunia kerja.

Selain itu, terdapat pula segresi gender yang dapat ditemui dalam pasar kerja di Cina. Segresi ini disebabkan oleh adanya perbedaan gender yang dihadapi dalam dunia kerja dan kaitannya dengan upah yang mereka terima. Hal tersebut mampu menjerumuskan pada adanya segmentasi gender dalam lingkungan para tenaga kerja, terlebih lagi yang berkaitan dengan pencapaian pendidikan para tenaga kerja. Jika dilihat dari bidang pekerjaan yang digeluti, maka bidang pekerjaan agrikultur menjadi bidang yang paling diminati oleh kaum perempuan di Cina. Selain bidang agrikultur, bidang operator, transportasi, dan layanan bisnis, menjadi bidang pekerjaan yang banyak digeluti. Walaupun begitu, dalam bidang - bidang tersebut kaum pria kerapkali lebih dipercaya dalam mengemban tugas sebagai pemimpin dari bidang pekerjaan terkait. Sejalan dengan itu, kaum perempuan dan laki - laki dapat dikatakan terlibat dalam jenis - jenis pekerjaan yang membutuhkan tingkat kualifikasi yang berbeda - beda dalam setiap bidangnya.

Kenyataan tersebut membuat partisipasi buruh wanita di Cina mengalami penurunan yang cukup drastis dari waktu ke waktu. Jika melihat pada sejarah yang ada, tahun 1990an menjadi saksi kunci di mana ketidaksetaraan gender di Cina semakin parah. Terjadi pemecatan terhadap puluhan juta pekerja wanita yang bekerja pada perusahaan - perusahaan milik negara. Pemecatan tersebut kerapkali disebutkan sebagai salah satu bagian dari reorganisasi perekonomian nasional (Fincher, 2013). Ditambah lagi dengan adanya adanya perlakuan yang tidak setara terhadap kaum pekerja wanita dan laki - laki pada saat itu. Setelah terjadi pemberhentian terhadap para pekerja dengan maksud melakukan reorganisasi perekonomian nasional, para pekerja wanita dipecat secara tidak proporsional dibandingkan dengan para pekerja laki - laki. Pun dalam rangka memperkerjakan kembali, kaum wanita mendapatkan pekerjaan baru yang tergolong berada pada tingkatan yang jauh lebih rendah dibanding para pekerja laki - laki.

Dengan adanya kesenjangan gender tersebut, Convention on Elimination of All Forms of Discrimination against Women (CEDAW) dirasa memberikan peranan yang cukup vital dalam upaya memerangi isu terkait. Seperti yang dipaparkan dalam konvensi tersebut pada artikel nomor 2 dan 3 yang 
menekankan target pada perjuangan terhadap kesetaraan gender (UNWomen.org). Dalam mandat artikel nomor 2 disebutkan bahwa isu mengenai kesetaraan gender harus diabadikan ke dalam sistem perundang - undangan negara masing - masing. Terlebih lagi untuk mencabut segala ketentuan yang bersifat diskriminatif dalam sistem perundang - undangan setiap negara. Perlu dibentuknya ketentuan - ketentuan baru untuk mencegah terjadinya diskriminasi terhadap perempuan secara lebih lanjut. Dalam mandate artikel nomor 3, ditenkan bahwa harus adanya kebebasan untuk mendapatkan kesetaraan yang fundamental dengan kaum laki - laki.

Konvensi ini telah banyak mempromosikan mengenai hak - hak yang harus dimiliki oleh perempuan dan bagaimana seharusnya kesetaraan gender itu dilakukan. Kemajuan global mengenai kesetaraan gender yang sangat signifikan telah terjadi dalam beberapa bidang kehidupan seperti partisipasi angkatan kerja, pendidikan, tingkat reproduksi, rata - rata harapan hidup, pembesaran hak - hak legal, dan sebagainya. Terlepas dari itu, ketidaksetaraan gender masih sangat akrab ditemui dalam bidang - bidang kehidupan lainnya. Perempuan kerapkali dianggap tidak proporsional dan masih terjadi polarisasi gender dalam kegiatan kegiatan perekonomian. Dengan begitu, apakah konvensi CEDAW yang telah turut serta diratifikasi oleh Cina sudah diimplementasikan dengan sebaik - baiknya oleh pihak Cina itu sendiri?

Untuk mewujudkan implementasi yang baik dari mandat yang ada dalam konvensi tersebut, diperlukan adanya perhatian lebih lanjut dari pemerintahan Cina dalam penerapan konvensi ini. Disebutkan bahwa penerapan dari konvensi ini tidak disertai dengan transparansi yang dilakukan oleh pemerintah. Data data terkait dengan proses pelaksanaan konvensi ini telah menjadi dokumen rahasia miliki negara. Ketidakterbukaan pemerintah Cina mengenai penerapan konvensi ini memberikan dampak yang cukup besar. Hal tersebut dapat merusak kemampuan Cina dalam menganalisa dan menilai bagaimana situasi kaum perempuan yang ada di Cina dan bagaimana solusi yang harus diambil dalam mengatasinya. Selain itu, hal ini pun berdampak pada terbentuknya batasan - batasan yang dimiliki oleh pihak - pihak non pemerintah untuk turutserta dalam usaha memperjuangkan diskriminasi perempuan dan kesetaraan gender yang terjadi di Cina.

Namun, terlepas dari itu, Cina melalui kebijakan - kebijakan yang dicanangkan sedikit demi sedikit mampu memangkas diskriminasi terhadap kaum perempuan dan ketidaksetaraan gender yang terjadi di sana. Kesuksesan tersebut harus menyadarkan pemerintah Cina untuk membenahi sistem yang diterapkan dalam proses implementasi mengenai konvensi ini. Pun banyaknya celah dalam ketidaksetaraan gender ini menjadi pekerjaan rumah yang cukup kompleks dan harus segera diselesaikan. Jika tidak, ketidaksetaraan gender ini akan meruak dan semakin membesar menjadi permasalahan yang sangat krusial. Tidak hanya mempengaruhi kehidupan individu yang termarjinalkan, namun lebih jauh lagi isu mengenai ketidaksetaraan gender ini akan meluas pada aspek - aspek kehidupan masyrakat lainnya.

\section{PENUTUP}

Implementasi dari Convention on Elimination of All Forms of Discrimination against Women (CEDAW) di Cina sudah cukup berhasil dilaksanakan. Namun, dalam pelaksanaannya terdapat beberapa hal yang memerlukan perhatian lebih dari pemerintahan Cina. Terdapat beberapa tantangan yang cukup serius dalam implementasian konvensi ini. Pengendalian informasi dan kurangnya transparansi pemerintah mengenai pelaksanaan pilar - pilar konvensi ini menjadi pekerjaan rumah yang harus dikerjakan oleh pemerintah Cina. Pun kesenjangan peraturan yang terdapat dalam hukum Cina dengan hukum internasional harus segera diperhatikan oleh pemerintah. Jika Cina tidak segera mengambil tindakan maka akan terjadi penerimaan 
informasi yang tidak memadai dan tidak jelas.

Berkaitan dengan ketidaksetaraan gender yang terjadi di Cina, Convention on Elimination of All Forms of Discrimination against Women (CEDAW) ini sedikit banyak sudah membantu untuk memperjuangkan kesetaraan yang diharapkan. Walaupun begitu, secara khusus kaum perempuan di Cina harus tetap berjuang untuk memperoleh kesetaraan gender untuk mendapatkan perlindungan, rasa hormat, dan pemenuhan terhadap hak - hak yang dimiliki. Lebih dalam lagi, reformasi dalam bidang legislative dan alokasi anggaran harus dilakukan untuk memenuhi hak - hak yang dimiliki kaum perempuan. Tidak hanya bagi kaum perempuan, kaum laki - laki pun berhak memperjuangkan harkat dan martabatnya jika diperlakukan secara tidak setara. Dengan kata lain, kaum yang termarjinalkan harus mulai berani untuk angkat bicara dan memperjuangkan apa yang menjadi hak - hak mereka.

Sosialisasi mengenai konvensi ini harus gencar dilakukan agar masyarakat Cina khususnya kaum perempuan mendapatkan pemahaman yang mendalam tentang hak - hak yang seharusnya mereka dapatkan. Pun pengendalian atas informasi yang relevan juga harus diperhatikan. Selain itu, masyarakat sipil harus dimungkinkan memainkan peran yang lebih penting dalam program pemantauan implementasi dari pilar - pilar konvensi ini, dan harus mampu bertindak dalam pengembangan solusi yang relevan dalam mengatasi permasalahan terkait. Jika implementasinya dilakukan terfokus, maka akan menghasilkan kesetaraan yang nyata dalam kehidupan baik kaum perempuan maupun kaum laki - laki di Cina.

\section{DAFTAR PUSTAKA}

\section{Jurnal}

China, H. R. (2006). Implementation of the Convention on the Elimination of All Forms of Discrimination Againts Women in The People's Republic of China. New York: Human Rights in China.

Chow, G. C. (2004). Economic Reform and Growth in China. ANNALS OF ECONOMICS AND FINANCE 5, 127-152.

Dasgupta, S., Matsumoto, M., \& Xia, C. (2015). Women in Labour Market in China. Bangkok: International Labour Organization.

Gautam Jaggi, M. R. (1996). CHINA'S ECONOMIC REFORMS: Cronology and Statistics. Institute for International Economics Working Papers 96-5.

Mai, X. P. (2008). Population Ageing, Labour Market Reform and Economic Growth in China - A Dynamic General Equilibrium Analysis. General Paper No. G-174.

Tisdell, C. (2008, October). Thirty Years of Economic Reform and Openness in China: Retrospect and Prospect. Economic Theory, Applications and Issues.

\section{Official Websites}

Society, C. W. (2014). A Brief Report on the Combined Seventh and Eighth Periodic Report. China. 